\title{
CHILDREN AS PREY: A CASE OF THE UTMOST Contemporary Legends of Organ Theft, Children's Disappearances, Kidnappings, and the Sexual Abuse of Children and Adolescents
}

\section{Véronique Campion-Vincent}

\begin{abstract}
This article discusses several sets of rumours and contemporary legends studied by the author since the 1990s. The common theme concerned with children as prey, victims of ruthless predators, unites narratives of organ theft, the social construction of disappearances and kidnappings, and sexual abuse of children and adolescents. In light of these facts, the denial of yesterday has turned into an ever-growing obsession. This paper examines children as prey through three subthemes, attending to the individual features and to the ways they overlap and also engage contemporary anxieties. An overview of recent events in the United Kingdom and France indicates the persistence of some scary and hazardous hypotheses regarding the children as prey theme.

The concluding remarks are presented in three parts: first, a review of key transformations in the discourse around the children as prey by the adoption of a different approach; second, an in-depth discussion of the well-known tale of the Slaughter of the Innocents, as always present in the successive sets of accusations linked to the emergence of collective faces of the Evil; and third, an analysis of the concept of the utmost, a special type of the extreme. Finally, the author's hypotheses on the contemporary obsession with child sexual abuse are presented.
\end{abstract}

Keywords: children, contemporary legends, moral panics, organ theft narratives, paedophilia, rumours

\section{INTRODUCTION}

This article examines a common theme in several sets of rumours and contemporary legends that I have studied since the 1990s. This theme is concerned with the children as prey, or the framing of children as victims of the malevolence of ruthless predators. As I will explain below, this theme is not directly expressed but rather presents itself as a conclusion one arrives at 'naturally', by taking into account a biased and hyperbolic presentation of evil, manifested at the 
very core of these rumours and contemporary legends. Following this logic, the children as prey unifies diverse figurations of evil. I also treat disappearances and kidnappings, and the sexual abuse of children and adolescents as facts that are socially constructed and manipulated through narratives. Such an approach allows me to discuss the radical change of attitudes that has also produced a major shift in the children as prey theme, and to suggest that these transformations require further study.

Following the chronological sequence of my previous research, I will first present organ theft legends in which presumed victims were children (CampionVincent 1990, 1997, 2005).

I will then discuss attitudes concerning disappearances and kidnappings, which have evolved from denial to obsession, followed by sexual abuses against children and adolescents (Campion-Vincent 2004, 2006, 2008). Although treated separately in this paper, the three themes overlap and also engage contemporary anxieties.

The children as prey theme is a case of the usage of the utmost, a rhetorical device of persuasion developed through hyperbole and extreme oppositions. Invoking the utmost can render what is exceptional - in this case, manifestations of the extreme evil - as commonplace events.

\section{ORGAN THEFT}

Accusations of systemic organ theft by organised networks appeared in Latin America around the end of the 1980 s, with the development of organ transplantation, following improvements in the control of rejection problems. Leaving aside the stolen kidney motifs that appeared and continue to flourish in wealthy nations and that focus primarily on adults, my discussion will focus on the representation of organ theft in the narratives that I call baby parts and eye thieves.

Baby parts narratives assert that the international adoption of children from poor and developing nations is characterised not only by irregular practices, but also by criminal ones. The babies adopted from abroad did not arrive in the homes of loving families but instead were sent to operating theatres where they were cut into parts by unscrupulous surgeons for patrons from rich countries.

In 1987, there were incidents in Central America (Honduras, Guatemala) in which the discovery of babies who had been kidnapped in order to be sold for adoption abroad was interpreted as proof of organised organ theft. Articles in the local press then picked up the accusations against 'the organ mafia' which circulated orally. These views regarding organised organ theft were 
endorsed by pro-Communist and pro-Third World press all over the world. Through the vigorous propaganda activity of the U.S. Information Agency and other U.S. agencies, several denials countered these accusations. However, on September 15, 1988, following an initiative from a French representative, Danielle de March, affiliated with the Communist Party, the European Parliament adopted an accusatory motion expressing condemnation of the trafficking of organs of Third World babies, which specifically referenced the incidents in Honduras and Guatemala, and identified Israel and the United States as complicit nations. The United States responded on July 15, 1989, with an official letter of protest that suppressed the publicly supported accusations.

In 1992, similar accusations regarding the diversion of international adoption surfaced in Russia and East European countries where international adoption had grown after the fall of the Iron Curtain.

The eye thieves narratives that appeared around the same time, in Central America but also in the Andean Region, Argentina and Brazil, relate the discovery of a mutilated body of a street child along with some money (a larger or smaller sum) and a hand-written note: "Thank you for the/your eyes (or kidney)". The murders of street children, often involving mutilation, reinforce the terror that the elimination of those deemed "disposable/discardable" intends to convey, and also appears to validate accusations of organised organ theft and the complicity of the state. For example, the fact that such murders often remain unpunished suggests that they are perpetrated with the complicity of authorities (police and militias hired by shopkeepers harassed and robbed by the street children), and the fact that the murders are executed semi-clandestinely reinforces uncertainty about their origin and nature.

Another motive in eye thieves narratives can also be found in the accusations targeting clinics and hospitals that allegedly kill or mutilate their patients in order to sustain a system of organ trafficking for the benefit of rich nations and individuals. In fact, a specific form of trafficking has existed for corneas - which are tissues and not organs and can thus be easily harvested after death - in mortuaries around unclaimed bodies.

Consider, for example, the accusations, followed by denials, in the case of the young Columbian Jeison, who, according to his parents, lost his sight because of the hospital's criminal activities. This case became a public controversy in France as a result of Marie-Monique Robin's movie Voleurs d'yeux (Eye Thieves, 1994), the (disputed) recipient of the 1995 Albert Londres Prize for journalism.

Widespread perceptions of the dangers posed to children by predatory foreigners did not diminish in Latin America: cases in point include the 1994 lynching in Guatemala of a U.S. citizen from Alaska, and another in 2000 (a Japanese national), and in Peru at the end of the 1980s of a Swiss citizen, 
which was followed by an urban unrest. These events have been detailed in various studies (Ansión 1989; Molinié Fioravanti 1991), which have also pointed to persistent tensions. The incidents in Guatemala originated with tourists taking pictures - acts that were interpreted by locals as preparing kidnappings of children for organ thefts.

Today there are no more public accusations of the kind. However, distrust of the abuses that international adoption might generate has led to an important diminution of the practice. Opinions are split as to the accusations. On the one hand, all elites and reasonable people deny the existence of organised networks of organ theft. There are numerous impossibilities, of which the most glaring is the multiplicity of actors in organ transplant surgeries, making secrecy impossible. There is also an abundance of organs for sale: why bother to steal organs you can buy? On the other hand, a massive fictional production is entirely oriented towards the validation of these allegations of the organised networks of organ theft. Furthermore, belief in the existence of these networks remains entrenched in the public opinion. There are two main reasons for this: first, the pessimistic conviction that in contemporary society "anything is possible"; second, a confusion with authentic scandals caused periodically by the persisting international organ trafficking.

Today organ theft accusations have declined. In 2014 they were still present among the accusations surrounding the ill treatment of prisoners in the Kosovo War, yet with no real consequences.

Organ theft accusations are often mentioned by sensationalist media to explain away a mysterious disappearance. A recent example occurred in the Netherlands in June 2014, when the news site www.ad.nl published a sensational story about two Dutch women who had disappeared in Panama, asserting that 'local sources' had revealed that they had fallen victim to an organ theft ring. Peter Burger, a specialist of contemporary legends, reacted, pointing out the story's many errors on his website (Burger 2014a), and the news site retracted the item (P. Burger, personal communication, June 12, 2014).

\section{FROM DENIAL TO OBSESSION}

The two subjects - disappearances and kidnappings, and child sexual abuse that I will discuss further down, have generated many legends, but it is important to remember that their origin lies in a radical change of attitudes towards recurrent facts. Previously these facts were not only ignored, but also explicitly denied; today they are recognised and have become obsessive focal points. This obsession seems to validate several breaches of the rule of law: 
The rise or disappearance of former prohibitions is always compensated by the resurgence or reinforcement of other taboos. As if society tried to get off lightly and ease its conscience. [...] The field of sexual delinquency implying minors is especially appropriate to this exercise. The legitimate and consensual emotion that invades us when suspecting sexual abuse troubles judgment: fantasy dominates, psychology regresses, and the Law abdicates. (Bensussan \& Rault 2002: 264) ${ }^{1}$

The emergence of major concerns about child sexual abuse in the United States during the early 1980s marked a radical transformation in social attitudes and stood in total opposition with more indulgent views that prevailed in the 1950s and 1960s (Jenkins 1998: 83-90).

This shift falls into the analytical domain of those studying the surge of social problems; here, the approach of constructivists - marked by the pioneer book published by Malcolm Spector and John Kitsuse in 1987 - has been decisive. Constructivists underlined the importance of the assertions of claims-makers in the evaluation of tense situations and remarked that the latter ignored the socio-economic constraints that played an important role in these situations; they aimed to transform these tense situations into social problems that could be solved through mobilisation alone (Spector \& Kitsuse 1987; Best 2002).

\section{DISAPPEARANCES AND KIDNAPPINGS}

The white slave trade kidnapping narratives will not be discussed here as these kidnappings - erroneously presented as the main source of prostitution - do not target children.

\section{Missing Children}

The missing children movement surged in the United States in the mid-1980s, amidst the unrest that resulted from a series of disappearances of which the best known is that of Ethan Patz (6 years old) in New-York on May 25, 1979, on his way to school ( 2 blocks). Ethan was never found but has been immortalised by the movement. Many countries, including France since 2003, mark May 25 as the Missing Children's Day, which was established in the United States in 1983.

The 6-year-old Adam Walsh disappeared on July 27, 1981, from a Sears department store in Florida and two weeks later his body (actually only the severed head, in a drain pipe) was found 62 miles from the place of his disappearance. His father, John Walsh, became a tireless activist whose deposition 
at the Senate has remained notorious for its exaggerations. In 1983, the TV movie Adam overwhelmed the United States. From 1988 to 2011 John Walsh hosted the television programme America's Most Wanted, whose website announced proudly its 1000th capture on May 2, 2008. In 2008 John Walsh opened the National Museum of Crime \& Punishment in Washington D.C., on 28,000 square feet $\left(2,600 \mathrm{~m}^{2}\right)$. In 1994, the National Center for Missing and Exploited Children (NCMEC, co-founded by John Walsh in 1984), launched - in collaboration with the U.S. retail giant WalMart - the programme called Code Adam. This programme developed a standard set of instructions to be followed by employees in the case of a missing child in a department store or a shopping mall, and it still stands as current protocol.

Named after another victim (9-year-old Amber Hagerman, 1996, Texas), Amber Alert is another child abduction alert system, one that specifically aims to mobilise and coordinate the media and authorities. It was adopted in France in 2006 .

The first names of other girls kidnapped and murdered by recidivists - the 12-year-old Polly Klaas (October 1993, California) and the 7-year-old Megan Kanka (July 1994, New Jersey) - are emblems standing for the repressive measures taken to control sex offenders having served their sentences. Thus long-missing children are remembered in the 21 st century through their association with these repressive measures that still persist.

An important polemic - still active thirty years later - began in the 1980s and focused on the accuracy of statistics concerning missing children. In 1982-1984 the figures were inflated beyond reason and "Senate and House committees were told that as many as 'two million children' disappeared each year and as many as 'five thousand were murdered through kidnapping and abduction"' (Fass 1997: 243).

Criticised already in 1985, these wild statistics were put to rest in 1990 by the pioneering and comprehensive statistical study of the problem of missing children, "National Incidence Studies of Missing, Abducted, Runaway, and Thrownaway Children" (NISMART), a study conducted jointly by the NCMEC and the U.S. Department of Justice. Two-thirds of the cases were related to runaways and thrownaways, family abductions being the next:

Among non-family abductions, NISMART has identified 3,200 to 4,600 child abductions / kidnappings per year. [---] In the NISMART study, the more restricted category, "stereotypical kidnapping," included only the most serious cases of longer detention or intentional abduction, and those in which the child was gone overnight, killed, or transported fifty miles or more, or there was evidence of intent to keep the child permanently. 
These cases [---] were comparatively rare, and in 1988 probably numbered between 200 and 300. [---] Finally, of the stereotypical stranger abductions, the report estimated that between 43 and 147 children had been murdered as a result. (Fass 1997: 243-244)

Comparable figures were quoted in the 2000s. But, as Paula Fass remarks:

The figures only seem small when compared to the initial inflation used to fan the campaign in the 1980s. [---] If the children disappear forever, as many of them do, if they lose their identities, their past, or their lives (and probably half fall into this last category), then the cumulative numbers over a decade become a terrible chart of social and personal loss. (Fass 1997: 254)

\section{Disappearances and Kidnappings in France}

At first, French institutions resisted the anguished claims coming from the United States. Towards the end of the 1980s, authorities refused to answer the requests of activists who tried to define, as major social problems, the disappearances and kidnappings of adults, about which the law was rather vague, and especially of children. It took, among other factors, several scandals for the attitudes to change for good in the 1990s, when disappearances and kidnappings became acknowledged facts: first, the Mourmelon disappearances of young soldiers - long denied by military authorities - that have remained mostly unsolved; second, judicial indifference in the case of the missing girls in care in the city of Auxerre, causing the long-term impunity of the serial murderer Émile Louis; third, the discovery of the long unpunished sexual murders of Michel Fourniret, who acted with his wife's active complicity (each of these serial murderers killed several victims under 15 years of age).

The first disappearance in France that generated an important mobilisation was that of Marion Wagon, on November 14, 1996. Six years later, that of Estelle Mouzin, also 9 years old, on January 9, 2000, led to a national mobilisation and the creation of a very active association. Both cases remained unsolved. Lacking concrete means of action, these mass mobilisations enacted symbolic gestures: white marches, balloons releases, etc., staging outraged innocence. 


\section{The Attempted Abduction}

In 1996, the legend of the attempted abduction, which had spread in the United States since 1978, began to circulate in France. A study authored by Mireille Donadini-Rousseau documented the circulation of this legend in the south of France (Donadini-Rousseau 1998). From a different source, a typical version, told by a person who claimed to have been a direct witness, is quoted here:

Mlle Gisèle Gourdon, [twenty-five, has two degrees and is working for her PhD in England] [---] had spent Christmas at her home in Fayence, Provence, and there she had heard a similar story from her mother, a village housewife of about fifty. [---]

"I [the mother] went to Mme Iehl to get the story of the kidnapped child. It's a true story, not a myth, and often happens in superstores, where security depends on closing off the exits immediately, because attempts at kidnapping take place very quickly without anyone being aware.

On 16 December 1996, Mme Iehl went to Nice Airport to buy tickets for her grandson, and then went shopping at Cap 3000 [a shopping mall] at St Laurent du Var, which is where it happened! A mother who had put down her purchases at the checkout noticed that she'd forgotten butter, and sent her little daughter back to get it, a child aged seven. Scarcely five minutes later, as the little girl hadn't come back, she became worried and reported it. The checkout girl gave the alarm, and all the exits were immediately closed. After a search, the little girl was found asleep in a changing-room, but with her hair cut short and wearing different clothes. The child was all ready to be taken away, but since the exits were closed faster than they had anticipated, the kidnappers didn't finish their work. It is not only in France that these kidnappings occur. [---]

Contacted by telephone, the security staff at Cap 3000 said there had been no such incident and they had never heard the story. (Roper 1997)

This narrative features an attempted kidnapping in a public setting where adults and children mingle - amusement park, shopping mall, department store - and generally ends well, since the child is found. But the story contains some grey areas: the failed kidnappers remain unidentified and are thus still free to strike again; also, the reasons for the attempted abduction remain unknown. The Code Adam protocol presented earlier is said to be applied so that once the alert is sent, the employees close the doors and start a general search that concludes in the recovery, in public toilets or in a fitting cabin, of the child who has been disguised or drugged and whose hair has been dyed or shaven, two very improbable elements as remarks a lawyer quoted by Jan Brunvand: 
"How do you manage to dye a kid's hair in public toilets? I'd rather give a bath to a cat" (Brunvand 1986: 150).

Another consequence of this atmosphere of anxiety is the recurrent circulation of "Wanted" notices on the Internet and social networks. These notices most often concern imaginary children or children already found and thus add to uncertainties surrounding disappearances.

\section{Situation in France in 2014}

In 2014, the situation in France was the result of an evolution that had started in early 1995, with the enactment of a law concerning the search for missing persons (Journal Officiel 1995: 1249).

This law was followed, in 2002, by the creation of the Office Central chargé des Disparitions Inquiétantes de Personnes (Central Office in Charge of Alarming Disappearances, OCDIP) (May 3, 2002), a centralising body requested by the militants. The existence of the OCDIP brought new importance to the development of statistics, as new measures adopted in September improved the law of 1995. However, in 2006, the Office Central pour la Répression des Violences aux Personnes (Central Office for the Repression of Violences towards Persons, OCRVP) integrated the missions of the OCDIP and of the National Division to counter attacks on individual persons.

In the long brief detailing of the new structure's multiple missions, the paragraph concerning alarming disappearances (all minors' disappearances are classified as alarming) seems lost amongst other missions that include the protection of victims of sectarian abuse:

The Office is also competent to investigate cases of:

Majors and minors disappeared in alarming conditions, whatever the cause of the disappearance. These investigations are conducted in accordance with the procedure considered in article 26 of the law of January 21, 1995, or in the frame of a criminal inquiry;

Discoveries of unidentified bodies;

Sectarian drifts creating penal infractions. ${ }^{2}$

Since 2006, the official statistics on alarming disappearances of minors, around 1,000 per year, are no longer accessible to the public. The American Kidnapping Alert (Amber Alert) model, adopted in 2006, was used ten times in 2013. Each time with success, but two per year is a drop of water in the ocean of disappearances (1,000 per year). A new federative association, 116000 Enfants Disparus, ${ }^{3}$ manages the European hotline for missing children, 116 000. It maintains a Facebook page and publishes annual reports. 


\section{CHILD (SEXUAL) ABUSE}

A seminal article published in 1962 by paediatrician C. Henry Kempe (Kempe et al. 1962) was a major factor in discovering the frequency of ill-treatment of very young children by their close kin. The study brought about a focus on intrafamilial abuses, including sexual abuse. Kempe campaigned successfully for the adoption of abuse reporting laws that made it mandatory for social workers or teachers to report situations of abuse to authorities. In 1972, Kempe created the National Center for the Prevention and Treatment of Child Abuse and Neglect, and in 1977 the International Society for the Prevention of Child Abuse and Neglect (ISPCAN), which fostered an international multidisciplinary journal, Child Abuse and Neglect.

The proper term is probably rediscovery as abuse in families was a subject of debate in the 19th century, as a consequence of the development of public hospitals. The subject was launched in France by Ambroise Tardieu's pioneering works, a book in 1857 and a lengthy article in 1860 (Tardieu 1857, 1860). Tardieu was rediscovered in the 1960s and the battered child syndrome is also called Tardieu's syndrome.

Since the 1970 s, a radical and nervous climate thus developed around children, and especially around the notion of the child as victim of sexual abuse by adults considered as absolute evil. A true moral panic seems to have seized the whole of society.

\section{Situation in France}

In France sexual abuse against children emerged as a subject of public concern in the late 1980s as witnessed by the growth of sentences for rapes of children (the judicial expression is "minors under 15 years of age"), multiplied by six from 1984 (100 per year) to 1993 (578). In 2000, the figures were close to those of $1993-599$ sentences.

In 1988, the French Department of Social Affairs organised its first public campaign against the sexual abuse of children. An abuse reporting law was adopted in 1989 and allegations and incidents of abuse needed to be reported to a local administrative body (the district's Conseil Général), which would then decide whether to implement measures to help the family or refer the case to a court. This 1989 law also established the lengthening of the limitation period for incest to ten years beyond the victim's majority. In 1993, a reform of the Penal Code confirmed the recognition of sexual abuse through a radical redefinition and renaming of "offenses to public morale" as "sexual aggressions". Very 
heavy sentences, up to 20 years of prison time, were then enforced, making France one of the most repressive of European countries.

In the 21st century France, the paedophile is the monster and a criminal who represents absolute evil. From Lille to Marseilles terrifying tales (mostly erroneous) of aggressions and kidnappings circulate, peppered with a zest of organ theft. Their examination shows that the themes of organ theft and kidnappings remain very close to the fear of paedophilia. Practically every week police forces are alerted about a sexual aggression against a child or a kidnapping that is generally revealed to be false. Some have caused very serious incidents (see the list in the appendix (Aron \& Cognard 2014: 126-138) concerning cases that took place in France in 2010-2011 and entailed police inquiries).

\section{Conspiracy of the Elites}

In the discourse of child sexual abuse, a prominent structural feature is the conspiracy of the elites, based on the assumption that child abusers generally belong to privileged social classes and are thus embedded in powerful and protective networks that enable them not only to obtain their prey but that also help them to hide their crimes.

This theme has been prominent in three cases that received significant media coverage in France.

Firstly, the case of Marc Dutroux from Belgium, who was perpetrator of several kidnappings and murders, which were discovered in 1996 and resulted in the sentencing of Dutroux and his wife in 2004. During the lengthy judicial inquiry, Dutroux had repeatedly asserted that he was "working for a network", and several media, even the parents of one of his victims believed this was the case. Furthermore, a whole array of sensationalist media fell for the extravagant accusations of Régina Louf, who maintained that she had seen the King of the Belgians participate in horse-riding child hunts where the hunters were equipped with bows and arrows in a walled-up secret park. Louf (who had certainly been a victim of abuse) was no longer considered a witness by justice after 1997 but several 'documentaries' uncritically spread her wild accusations.

Secondly, the case involving the city government of Toulouse (sadism and murder accusations orchestrated against the Mayor Dominique Baudis, who in 2003-2005 was accused of having ordered murders from a murderer Patrice Allègre, convicted in 2002. The accusations were picked up in the media: thus the reference daily Le Monde, dated June 17, 2003, published a sensational "Affaire Allègre: Les enquêteurs reconstituent l'histoire de la maison de Noé" (Allègre Case: Investigators reconstruct the story of the Noe's house), filled with 
juicy details describing the hypothetic place of the supposed orgies and "red masses with animal sacrifices". But Le Monde apologised in September and the author of the article publicly admitted that he had been repeating hearsay.

Thirdly, the case of Outreau (intrafamilial rapes transformed with the active participation of convinced therapists into a supposed case of paedophile sex networks, which entailed numerous arrests in 2001-2005). Those arrested for participation in a sex network were freed and compensated after being exonerated by the second trial in 2005, with the exception of the parents and another couple of neighbours. However, in 2013, eight years after the second trial, participants of the 'sex network' version are still very present. This topic will be taken up later.

\section{Satanism Scare}

It was in the late 1980s that accusations of satanic ritual abuse became topical in the United States. The Satanism Scare (Richardson \& Best \& Bromley 1991) was a complex phenomenon influenced by the beliefs and actions of many different actors: religious fundamentalists, psychiatrists, and psychologists engaging in an uncritical use of hypnotic regression techniques that often created false memories, as well as feminists for whom these supposed horrors exemplified masculine tyranny. The accusations also relied on inflated statistics of disappearances erroneously quoted by the missing children movement to legitimate the extreme assertions made in The Satanism Scare that missing children were often sacrificed during cannibalistic ritual orgies. The supposed link of Satanism with disappearances seemed to give weight to assertions that are discredited today but still believed in certain circles that continue to practice uncontrolled hypnotic regression techniques.

Jean La Fontaine, an anthropologist in charge of an official inquiry on satanic ritual abuse accusations that impacted social services personnel in Great Britain through biased seminars given by their U.S. counterparts, analysed the survival of discredited beliefs:

This contemporary social movement has evolved, relying after 1995 no longer on children's assertions but on adult "survivors" as patients rather than saved souls. The movement drew on different strata of British society: In the first phase "Christian fundamentalist fighting against the occult, feminists and social workers who had been convinced there was a new threat to children [...], professionals in the psychotherapeutic community supported by certain feminist activists" in the second phase. (La Fontaine 1998: 160) 
While in France the satanic ritual abuse movement only spread to limited circles of evangelist Christians, many French professionals, psychotherapists, feminists, and activists took up the idea that "the acceptance of the stories of the victims as true, even or perhaps especially when they seem incredible, is a demonstration of support and may be experienced by the teller as healing" (ibid.: 6). The origins of the French Outreau case, which led to the erroneous indictment of many innocent persons who were accused of active participation in imaginary sex networks (see above) are evident in this quotation.

\section{Repressed Memories of Sexual Abuse}

In the late 1980s several American psychotherapists and psychiatrists adopted the theory that memories of traumas - and especially of sexual abuse during childhood - were often repressed and that the recovery and rebuilding of these lost memories through hypnosis was a miraculous remedy for 'survivors' who had previously been mistreated by their parents. Accompanying this theory was the notions, that survivors often developed multiple personalities - 'alters', whose manipulation and evocation by the therapist could induce the cure. In addition, some believed that abusive parents were often active members of satanic cults (see the earlier discussion).

The Courage to Heal: A Guide for Women Survivors of Child Sexual Abuse by Ellen Bass, a poet and creative writing teacher, and Laura Davis, an incest survivor, was an international bestseller with four editions from 1988 until 2008. It became the bible of the movement. Bass and Davis had no training in psychotherapy and "defended their lack of training, saying that a $\mathrm{PhD}$ is not necessary 'to listen carefully and compassionately to another human being". Their approach was simple, even simplistic: any disturbance or social maladjustment was the consequence of sexual family abuse, suffered in early childhood, repressed and forgotten. These memories could be recovered through hypnotic psychotherapy leading to cure. They thus defended "the vision that childhood sexual abuse could be discovered with no corroborating evidence beyond a vague set of symptoms". ${ }^{4}$

The theory was applied with messianic zeal. Utilising hypnosis, dream analysis, guided imagery, and regression towards previous ages, the convinced therapists persuaded their patients, mostly women, to 'recover' from the sexual abuses that marked their childhood, generally abuses perpetrated by their fathers or step-fathers, sometimes with the active participation of their mothers. More-over, many of these patients became convinced that they had developed multiple personalities and the orientation of their therapy in that direction aggravated their condition: 
Disintegrating even more, these unfortunate were then sent in costly clinics specializing in "dissociated identities" where their fantasies to harbour five, a dozen or up to hundreds of alternative identities were flattered until, their insurance policy being over, they were abandoned in a lunatic state. At the top of the panic, some traumatologists considered that "from twenty to fifty per cent of psychiatric patients suffer from dissociative disorders". (Crews 2004; quotation Van der Kolk \& Van der Hart 1991: 432)

The attacks led by psychologists and psychiatrists that did not subscribe to the theory of repressed memory were decisive and effectively discredited the allegations of the survivors who had recovered their memories through hypnosis, as well as the depositions of children obtained through suggestion. A seminal book to turn the tide was published in 1994 (Loftus \& Ketcham 1994).

While professionals were anxious to maintain "the recognition and treatment of sexually abused children" (Brandon et al. 1998: 296), they realised the danger of resorting to methods that created fictions and distanced themselves from them, specifying, for example, that "when memories are 'recovered' after long periods of amnesia, particularly when extraordinary means were used to secure the recovery of memory, there is a high probability that the memories are false" (ibid.).

\section{Abuse by Strangers, Sexual Predators}

It has been shown earlier that alarming kidnappings by strangers constituted only a small percentage of disappearances of minors. However, public attention has focused on these relatively rare cases. The irrational violence of evil characters striking at random victims raises emotions and these horrors seem easier to solve radically than the more complex cases of violence within the family, which occur frequently in socially deprived groups. These more numerous cases are neglected, do not become 'good' subjects for large-scale media, and do not generate urban legends. The media and human interest stories that attain a legendary status centre on white children of the middle classes who inspire dramatic tales and vigilante-oriented action. According to the logic of these tales, the problem does not concern social organisation, and society in general does not incur any responsibility since it is the work of evil individuals. Proposed solutions tend to advance this theory of the problem's origin: a better implementation of law, more severe sentences of imprisonment, and enlargement of prisons rather than development of social programmes (Conrad 1998).

At the beginning of the 1990s an extreme view on child abusers became prevalent in the United States. They became considered as potential recidivists 
beyond redemption. The expression 'sexual predator', already used in sensationalist crime fiction, did not reach the press until 1987, and was still infrequent in 1987-1989, but it appeared 140 times per year in 1990-1992, 321 times in 1993, 865 times in 1994, and 924 times in 1995 (Jenkins 1998: 189-214).

In 2007, the official website of the U.S. Immigration and Customs Enforcement launched Operation Predator, still active in 2014 and self-defined as "an ongoing enforcement effort targeting those who prey upon and sexually exploit our nation's children - including Internet pornographers, international sex tourists, and foreign national sexual predators". ${ }^{5}$

Moreover, as Philip Jenkins notes, it is commonly asserted that sex abusers have invaded cyberspace, which has thus become terribly dangerous. This surge of fear exemplifies the adaptation of the fears of sexual abuse of children to new environments (Jenkins 1998).

In 2014, specialised police units hunted down 'cyber-predators' in France by infiltrating meeting sites that connect to young female adolescents. Early in 2014, Terre des hommes Netherlands, a Dutch branch of the Swiss organisation Terre des hommes (Land of Men) based in The Hague, announced proudly to have invented a 'bait-child' called Sweetie, and thus to have succeeded in tracking numerous predators. The picture, meant to terrify, shown on the organisation's Facebook page, is worth reproducing.

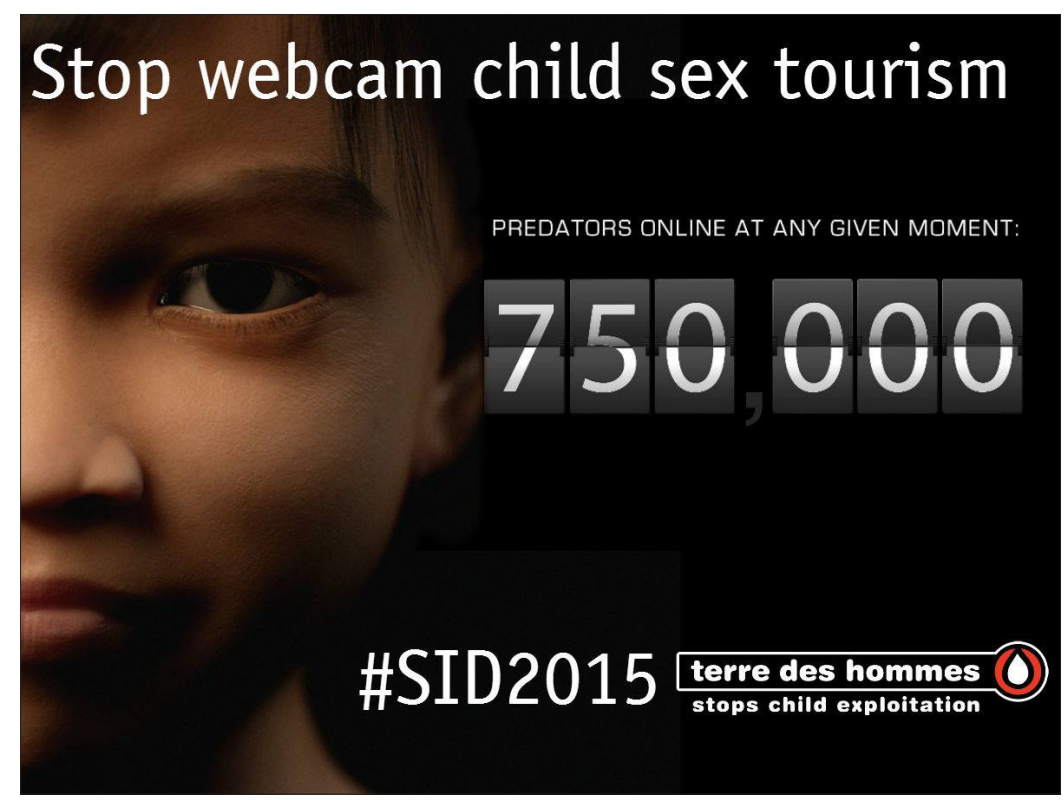

Figure 1. https: / / www.facebook.com / Sweetie.International / photos / a. 80436180 9576476.1073741828.803980692947921 / 930457996966856 / ?type=3\& theater, last accessed on November 17, 2015. 


\section{Hunting Down Potential Recidivists}

In the United States the programmes for the prevention of sexual abuse delivered in schools since the 1980s shifted in the 1990s, to focus on dangers caused by chance encounters, 'stranger danger'. Murders by recidivists of young victims met by chance have had a huge impact and have led to the adoption, strongly encouraged at the federal level, of laws and administrative measures planning mandatory treatments (behavioural, psychiatric, and chemical), police surveillance, and reporting to local communities, for those who have been sentenced for child sexual abuse and have completed their imprisonment. At the level of each state, information is increasingly being shared: records (including names) of those who have been formerly sentenced, the motives of their sentences, their descriptions and addresses are compiled and published by the authorities. Jenkins notes that in 1998 the records made public by the State of California contained the names of 64,000 liberated sexual abusers (Jenkins 1998: 189-214).

As anticipated, these measures consequently led to numerous attacks against those who had been convicted and then released. The reporting practices were contested by certain lawyers and magistrates as they effectively constituted informal extensions of prison sentences; however, they were still followed in 2014. One of the recent measures is the Adam Walsh Child Protection and Safety Act (July 27, 2006), which imposes strict controls on those deemed the most dangerous sexual abuse offenders, including the requirement that they declare their residence to authorities every three months, and paves the way for an integrated reporting and surveillance system at both local and federal levels. In March 2007, nineteen U.S. states maintained retention centres for sex offenders who had completed their sentences, and other such centres were planned, especially in the State of New York. The results of these treatment centres, which handled 2,900 sex offenders who had completed their sentences, seem disappointing and very difficult to evaluate. Furthermore, one must take into account the fact that there are few professionals receiving recognition from their peers, among those who have received lucrative contracts to implement the treatment programmes (Davey \& Goodnough 2007a, 2007b, 2007c).

\section{CHILDREN AS PREY IN 2014}

\section{The United Kingdom}

In the United Kingdom, the posthumous revelation of numerous sexual abuses perpetrated by Jimmy Savile (1926-2011), a TV and charity fundraiser per- 
sonality, created a scandal. It developed into an investigation of past sexual abuses carried out by other living media celebrities, which was not devoid of hysteria, hype, and fabrication. In general, there was little protest regarding the allegations and sensational media coverage.

Launched in October 2012, after the screening of Exposure: The Other Side of Jimmy Savile, an ITV documentary that denounced Savile's many abuses, Operation Yewtree, an inquiry headed by the Metropolitan Police, examined the numerous allegations that circulated after Exposure. Published January 11, 2013, the report, Giving Victims a Voice, ${ }^{6}$ was co-written by the Metropolitan Police and the National Society for the Prevention of Cruelty to Children (NSPCC). It disclosed the inquiries concerning Savile, including 450 allegations and 284 criminal offences, but also revealed other inquiries into sexual abuses by living persons, which involved prosecutions. Operation Yewtree was justified in the introduction as follows:

Savile was able, through his celebrity status, to 'hide in plain sight' while abusing children and adults over six decades [---] We must use the learning from these shocking events to prevent other children and vulnerable adults being abused in the future. They will get a voice. (Gray \& Watt 2013)

The critics, infrequent and marginal, raised interesting points: What was the point of "putting the past on trial" (Hume 2013)? Was it the police's mission to ask "anybody who claims to have been abused by a public figure in the distant past to come forward" (ibid.)?

The idea of conspiracies to abuse children, though unofficial, had not disappeared, remarked Jean La Fontaine, and, as the Satanic explanations were discredited, had become "non-religious in appearance but no less zealous and demonological in essence" (Black 2013). The deep unity between "the Satanic panic of the early 1990s and the post-Savile celebrity witch-hunt of today" was "the near existential need among certain sections of society for the existence of evil" (ibid.). La Fontaine had remarked in her 1998 book that today the sexual abuse of children was the most potent representation of evil.

Frank Furedi stressed the mix of reality and entertainment in Operation Yewtree, especially regarding the public response to its revelations. Recalling the TV series, To Catch a Predator, launched in the United States in November 2004, in which investigators impersonated youngsters to bait 'predators', leading to arrests on camera where "potential sex predators were put in the spotlight in order that they might be humiliated and punished for their behaviour" with the active participation of the police, Furedi concluded that "sometimes it seems that even the people involved in official inquiries into alleged past behavior also struggle to distinguish between media reality and reality itself" (Furedi 
2013b). Furedi authored a book on the subject (Furedi 2013a) that received a very severe review in The Guardian, which judged it as insensitive and short-sighted, saying: "[Furedi] sidesteps the 'victims' completely. He shows no interest in them, Savile or the culture in which this abuse was prevalent" (Moore 2013). A more measured review in the Times Higher Education was also unfavourable, arguing that Furedi was too narrowly focused on the denunciation of moral crusades to treat fully the questions raised by the treatment of the Jimmy Savile case (Egan 2013).

These criticisms are marginalised in the British media, even if one article written by academics takes the same approach and mentions moral panics (Cree \& Clapton \& Smith 2014).

\section{France}

Controversy over the Outreau case (see above) that developed from 2001 until 2005 , is still alive today, with a minority defending the notion that there really was a sex network, although the second trial of 2005 dismissed the idea when only the abusive parents and another couple were sentenced, and the other adults supposedly involved in the 'sex network' were freed and compensated. In February 2013, accusations surrounding the case took the form of a film that was released in theatres. The screenplay was written by Serge Garde, a retired journalist who had belonged to the communist daily L'Humanité and had formerly co-authored with Laurence Beneux, journalist in the conservative daily Le Figaro, a book that fully endorsed sex network hypotheses in paedophilia cases (Beneux \& Garde 2001). Interviewed at length in the movie, psychologist Marie-Christine Gryson-Dejehansart, whose partisan expertise had been severely criticised during the Outreau second trial of 2005, continued to defend the exclusive truth of "la parole de l'enfant" (the child's word) (Gryson-Dejehansart 2009). Chérif Delay, the main victim of repeated rapes perpetrated by his own parents and now an adult, was also interviewed. Delay had co-written a book with Serge Garde, describing his terrible experience but also defending the sex network hypothesis (Delay \& Garde 2011). Delay toured the conference circuit with journalist Jacques Thomet (Thomet 2013) to defend their theory of a paedophile network. While the hypothesis of a criminal conspiracy is invoked in the Outreau case, it is not a conspiracy of the elites since the parties do not belong to the elite classes.

Reworking several unsolved cases of disappearances, the sensationalist journalist Karl Zéro's recent book presentation resumes the 'networks' theme: 
Where is Maddie McCann, the 4-year-old little English girl who disappeared in Portugal? Who kidnapped Estelle Mouzin? [---] Karl Zéro has reworked all these cases, one by one. [---] This book sheds a new light on these files of unsolved disappearances. It reveals the dysfunctions of the law and the existence of networks that some obstinately deny. (Zéro 2014)

These themes and cases are echoed on the website Égalité et Réconciliation (Equality and Reconciliation), created by influential populist Alain Soral. ${ }^{7}$ Soral produced 55,900 YouTube videos in 2014 and 5,200 of these (almost 10\%) concern paedophilia envisioned as a characteristic of the 'new' Zionist elites he opposes. Jacques Thomet's book has been published by Kontre Kulture, Alain Soral's publishing house.

What we see here is a case of instrumentalisation, where child sexual abuse cases are assimilated into a conspiracy of the elites, of which they constitute an especially horrible occurrence, situated in the realm of propaganda and not that of legend. An analysis of the exploitation of these themes in extremist fringes of society is beyond the scope of this paper; however, the assertions of the extremists are important as they are a powerful conduit of legends.

The situation is very different in the United Kingdom and France. In the former, people contesting the network hypotheses are on the margins, in the latter it is those who defend the legitimacy of the networks that are marginalised. But an in-depth study would certainly show that the approaches in the public are more complex than they seem to be in these two countries. These hypotheses are not situated in the realm of rational analysis. Adhesion to them is fleeting and the idea that terrible crimes are committed according to some master plan can be harboured, albeit often briefly, by each of us, especially when we discover a new horror through the media.

After investigating the emergence of legends in the three different domains of (1) organ theft, (2) the reinterpretation of disappearances and kidnappings, and (3) new approaches to child abuse and child sexual abuse, it is important to recall that, although they had to be discussed separately, these issues are all linked to the defence of children. This convergence over the defence of children resonates in the various panics and reactions in which they can also be found.

\section{CONCLUSION}

Concluding remarks will unfold in three parts: firstly, a review of the transformations in the discourse of children as prey, as brought about by the adoption of a different approach; secondly, an in-depth discussion of the tale of the 
Slaughter of the Innocents, as an always present sub-text in successive sets of accusations that involve the emergence of collective faces of Evil; and thirdly, an analysis of the concept of the utmost, a special type of the extreme.

\section{A New Approach Transforms the Phenomenon}

When it comes to ill-treatment, disappearances, and sexual abuses targeting children, what weight should be given to the increasing number of statistics compiled to approach these social problems? In his book on statistical illusions, Joel Best builds on his previous studies (Best 1987, 1990) about missing children in his review of well-known facts. A social problem supposes certain definitions - variations of these definitions can radically modify perceptions of the problem. Thus, most cases of ill-treatment and child sexual abuse were not reported before 1960 . Then the age of childhood was changed to include adolescents, and "if in 1963 there were about 163,000 reports of child abuse, there were nearly 3 million in 1995" (Best 2001: 99). Should one consider that ill treatment and child sexual abuses have grown exorbitantly? Rather, an entire apparatus of detection and reporting has been set up, enlisting professionals to report all detected cases:

The figures of statistics measure not the frequency of the problem but new social attitudes and organizational schemes set up. However [in paedophilia cases, for example] militants stress these figures as proofs of the increasing seriousness of the problem and the need of new actions to conquer it. (Best 2001: 102)

Both social psychologists and folklorists have studied rumours. The former have focused on the social context and analysed the conditions under which rumours are generated, which generally involve a situation of crisis and uncertainty and the lack of trustworthy information (always true in this 'information explosion' age, if you insist on trustworthiness). Folklorists, on the other hand, have identified traditional narrative motifs in several successive waves of rumours and shown that these motifs can be transmitted through the continuous narration of legends, but can also, when social conditions are fulfilled, give rise to rumour panics (Klintberg 2014).

\section{The Slaughter of the Innocents}

The central question is that of the spontaneous, unthinking first move: the acceptance of the legends of organ theft, reliance upon the assumption that 
disappearances and kidnappings of children are mainly of collective and organised criminal origin, or adoption of the terrifying hypotheses that seem to cover all child abuse and child sexual abuse. This first impulse towards unthinking acceptance has deep roots, which must be considered in the sphere of symbolic thought, where symbols and fables flourish, where fears and wishes become fixtures in exemplary tales of horror. The names given to this sphere of thought vary from one author to another: for Claude Lévi-Strauss it is the savage mind (Lévi-Strauss 1962), for Michel-Louis Rouquette - natural or social thought(Rouquette 1973), for Nicole Belmont - mythical thought (Belmont 1984 [1968-1974]), for Peter Lienhardt - metaphorical or analogical thought (Lienhardt 1975). It is within each person (as is now recognised) that this symbolic thought mode 'alternates' with that of rational and reflexive thought so that two opposed approaches can coexist.

Magical reasoning attributes extraordinary powers to body fluids and extreme efficiency to innocence. These ideas contribute to universal conceptions of exchange and sacrifice that persist in the modern world and that can even be said to be gaining ground today with the growing popularity of alternative beliefs and lifestyles that repudiate the dictates of science and rationalism.

Centred on the preys, or the victims, the legends that I have discussed point to organised organ thefts, criminal kidnappings, and abuse by quasisupernatural predators that prowl about among us. It is evident that in the 21 st century, criminals occupy the space that in traditional societies was devoted to malevolent entities. They bring to mind the immemorial tale of the slaughter of the innocents, known more or less by everyone.

The core of this tale, which has been embedded in numerous stories in multiple cultures for centuries, is that young children from the storyteller's social group are being abducted and murdered, or ritually slaughtered, by evil-doers. The main outlines to be found in these various cycles can be summed up as follows:

Conspiracy is unmasked. An incomprehensible and meaningless coincidence is replaced by something that makes sense of the situation, although it is malevolent in nature.

- Victims are the children of the group, simultaneously its weakest elements and the embodiment of its future. Their extreme innocence makes them magically powerful and hence precious to the evil-doers.

- The evil-doers are, most often, either hostile foreigners or members of culturally different minorities living within our 'normal' society. But they may also be social deviants who seem, at first, to belong to our culture, e.g. criminals, heretics, or sorcerers. 
- This extraordinarily adaptable story can express normal people's fear of deviants, minorities, and foreigners, but also the ruling elites' fears of the poor and minorities. The evil-doers can also be the group's own rulers, own elites. This has been especially true in situations of colonisation or conquest, where the rulers were foreigners.

- The victims are eaten, emptied of their blood or their fat, and their vital forces are absorbed by the evil-doers. Often the evil-doers are sick or in some ways defective, and the victims possess the precious and unique element that can cure them or supply what they lack.

Christian culture has developed specific narrative cycles that incorporate and adapt the tale of the slaughter of the innocents. Thus, by denouncing outsiders, the ritual murder targeted Jews - or, the devilish pact is said to involve witchcraft.

The tale is extremely flexible and can express dominant fears, but also those of marginalised groups. The Topsy/Eva cycle identified by Patricia Turner (1993), in which identical rumours circulate in polarised communities and are adapted to make sense in each, comes to mind. The tale is then inverted as one of these optical illusions whose salient features become hollow and target the elites. In colonial and post-colonial societies the foreign masters, and today the rich, having adopted modern ways, continue to be perceived as vampires and sorcerers who devour children.

Dark legends play an important role as a mobilisation tool when a new social problem appears - or, rather, when a condition is successfully designated as a new social problem by claims-makers. Dark legends are elaborate versions that overstate disturbing facts, conflict-ridden social situations, and tense situations between social or ethnic groups. Often disseminated or fabricated by propagandists who find in these disquieting and sensationalist tales a way to mobilise publics for their own interests, these cycles of dark legends have followed and referenced each other by adapting themselves to the diverse historical circumstances from which they have emerged. It is most often the long-standing tale of the slaughter of the innocents that serves as a catalyst for these chilling tales and demonologies.

\section{The Extreme, the Concept of the Utmost}

Contemporary legends often seem to be rhetorical exercises built on the two processes of hyperbole, or the practice of exaggerating with the goal of attracting attention and advancing a particular view, and of extreme oppositions.

Hyperbole, which is a conscious exaggeration in order to persuade, is a standard tool of the claims-makers. In his recent analysis of Crime Legends, 
Peter Burger (2014b) discusses its use in the 'drugged and abused' (white slave trade) and the 'Smiley Gang' themes.

To stage extreme oppositions, the legends employ metaphors revolving around the theme of the utmost, to which I will now turn.

French dictionaries (Larousse 1869; Rey 1994) specify that the utmost, a dramatic form of the extreme, is both the most of (from the Latin culmen: the highest) and too much of (from the Latin cumulus: excess of). Different in their proper senses, the two Latin terms are united when used figuratively, always in a pejorative sense.

One example of the utmost of savagery is the exotic big cat, whose pseudoappearances have haunted the French and British countryside since some fifty years; the utmost of cruelty are these razor-blade cuts at the corners of the mouth inflicted by the Smiley Face Gang to their victims and that have disfigured Victor Hugo's Laughing Man (L'homme qui rit, 1869), as well as the Joker in Batman.

The notion of the utmost was introduced in 1962 by semiotician Roland Barthes in his analysis of the structure of fait divers (roughly equivalent to the human interest stories in U.S. newspapers in the 1940s). Barthes pointed out then that the fait divers was built up through the presentation of a dysfunction in the relations of causality and coincidence. Especially important were these coincidences so perfectly opposed that they overturned stereotypes. Barthes' example was the headline, "In Little Rock (AR) the police chief murders his wife" . Such extreme coincidences become meaningful, transforming chance or hazard into fate or destiny. In the rhetorical construction of these 'utmost' oppositions events become signs, but signs whose meaning is practically impossible to decipher (Barthes 1972).

In their 1947 Psychology of Rumour, social psychologists Gordon Allport and Joseph Postman used three terms to describe the movement of rumour: levelling, sharpening, and assimilation. The sharpening process, which refers to the selection of details in the transmission process studied by the authors, can be incorporated in the evolution towards the extreme. It is thus clear that resorting to the utmost is a reinforcement process, broadly spontaneous, which structures the understanding of faits divers and the elaboration of the plots of many contemporary legends.

\section{The Obsession}

After centuries of denial and neglect, what are the reasons for this long-lasting obsession with child abuse, and especially child sexual abuse? In a society 
plagued by uncertainty, and fearing the future, the notion that contemporary evil can be explained by looking to a demonised past may seem to offer a solution.

The taboo against sexual relations with youngsters has grown in parallel with the development of sexual permissiveness. Between consenting adults, everything is possible. Society organises and exacerbates desire but the means of its fulfilment are not provided.

If evil is situated outside, in the almost demonic sexual predator, the question of our own urges that may be evil need not be raised, and it is convenient to forget that $92 \%$ of sexual abuses are perpetrated within the family and close circle of friends.

It is impossible to dream of a return to the good old days of silence and denial; it is only by renouncing the eradication of evil as a goal that the combat for children can be both compassionate and rational, as well as truly effective. ${ }^{9}$

\section{APPENDIX}

\section{Imagined Sexual Aggressions and Molestation of Foreigners Erroneously Identified as Paedophiles, France 2010-2013}

(Aron \& Cognard 2014: 126-138)

Practically every week police forces are alerted about a sexual aggression against a child or a kidnapping that is revealed to be false. The following list concerns cases that took place in 2010 and 2011 and entailed police inquiries:

Reims (east of France), September 16, 2010. A paedophile dressed as Zorro is said to try to kidnap children near schools.

North of France, September 30, 2010. A couple in their sixties (she is a redhead wearing thick glasses) is said to drive near schools, trying to kidnap children. A Facebook page is created.

Bonneville (southeast Alps), early 2011. An English couple that has stopped to ask directions is mistaken for a pair of kidnappers and the police surround the village school.

Delle (near Belfort, east), January 26, 2011. A mother complains at the police station that two men in a white van, one of them bald, have tried to kidnap her 9-year-old daughter leaving school, by offering her sweets. Fantastic tales then surge in the community, thus Eastern Europeans are said to have killed four people leaving a nightclub (and stolen their organs). The police organise an investigation of all white vans to calm the people, thus validating the crazy rumours.

Lèves (southwest of Paris), January 2011. Rumours of sexual fondling entail the medical examination of a little schoolgirl. 
Allier (central France), January 2011. An outdated picture of a sexual criminal circulates and causes panic.

Côtes d'Armor (Brittany, west), February 2011. A white van with a kidnapper of little girls and organ traffickers.

Toulouse (southwest), March 2011. The same story of a white van, a kidnapper, and organ traffickers.

Strasbourg (east), April 2011. The same story of a white van, a kidnapper, and organ traffickers.

Picardie (northeast), May 2011. The same story of a white van, a kidnapper, and organ traffickers. The mayor of Beauvais denies it.

Lille (north), June 2011. The same story of a white van, a kidnapper, and organ traffickers.

Teil (southeast), June 2011. Two little girls escape kidnapping outside a school.

Three more serious incidents occurred in this climate of fear. In Marseilles (south), in May 2008, the disappearance of Fatima Saiah (aged 21, on her way to a baby-sitting appointment; still unsolved in 2014) entailed a strong community mobilisation. Shortly afterwards, the rumoured white vans driven by Eastern Europeans belonging to the 'organ mafia' are said to have been prowling around schools to kidnap children. On June 21, 2008, the day of the Music Feast, when everyone was outside dancing, three men who were Roma from Romania - a community of some 1,500 was settling in these Northern districts of Marseilles mainly inhabited by populations originally from North Africa were spotted searching in refuse bins for copper bits. They were designated by an excited crowd as 'the organ thieves', their van was burned, they succeeded to escape and found refuge on the roof of a snack bar where it took over 40 police officers with Flash Balls to liberate them from the lynching mob and take them to a hospital. No charges were filed.

On November 28, 2011, in Brest (Brittany), a 65-year-old Jean Claude Basset was smoking outside the apartment where he had been staying since April, just across the kindergarten school. This retiree with a strong southern accent (he used to work in the shipyards at Toulon) and of a rather shabby appearance, was under care for mental health issues and had been hospitalised for depression. On November 18, he had helped to bring back to school a 3-year-old little girl who had disappeared before her mother's eyes and this incident aroused the neighbours' suspicion. Suddenly some 10 to 15 mothers who were waiting for their kids outside the school rushed upon him, shouting insults. He took refuge in the building's hallway and shortly afterwards the police arrived. The policemen handcuffed him and transported him in their van when suddenly he fell on the floor, victim of a heart attack. A cardiac massage proved futile 
and Basset arrived dead at the city hospital. Since he carried no trace of blows, no charges were filed - the assailants were considered as 'actors of good faith' and the prosecutor declared to the press: "It is rumour that killed Jean-Claude Basset".

August 31, 2013. When the ferry Excelsior, coming from Marseilles, landed in Ajaccio (Corsica) in the evening, a pre-riot atmosphere broke out, fuelled by several alarming messages from mobile phones. It was said that "a group of kids back from a trip to Barcelona have been targeted by a party of Roma on the ship. There have been sexual fondling, kids - boys or girls - cornered in an elevator, pictures taken..." (Luccioni 2013).

The ship's captain identified 16 men, aged 30 to 50, who did not speak French; the police took them ashore and then to the police station in vans that passed with great difficulty through the crowds of people who were shouting insults and hitting the vehicles. Two kids talked to the police but no inappropriate conduct was detected. It appeared the kids were playing ball in the ship corridors and the men briefly joined in. The ball was taken - and given back. The men were Portuguese and regular farm workers in the vicinity of Ajaccio, their mobile phones revealed no inappropriate pictures and they were released. The comments of the article published the following Monday can apply not only to Corsica but also to France as a whole:

The facts are revealing. Fantasies that occur in a part of the population, which routinely sees in the other, especially if it is a foreigner, an immediate threat. And reveals the hidden face of a Corsican that cowers for imaginary terrors sustained by rejection and xenophobia. Worrying. (Luccioni 2013)

\section{NOTES}

1 Hereinafter translations of the quotations not originally in English are from the author.

${ }^{2}$ See www.police-nationale.interieur.gouv.fr/Organisation/Direction-Centrale-de-la-PoliceJudiciaire/Lutte-contre-la-criminalite-organisee/Office-central-pour-la-repression-desviolences-aux-personnes, last accessed on July 28, 2015.

3 See http://www.116000enfantsdisparu.fr/presentation.html, last accessed on July 28, 2015.

4 See https://en.wikipedia.org/wiki/The_Courage_to_Heal, last accessed on July 28, 2015.

5 See http://www.ice.gov/news/releases/internet-predator-group-member-sentenced-15years-prison-engaging-child-exploitation, last accessed on July 28, 2015. 
6 Available at http//content.met.police.uk/News/Giving-Victims-a-Voice/1400014181251/1257246745756, last accessed on July 28, 2015.

7 See http://www.egaliteetreconciliation.fr/, last accessed on September 10, 2015.

8 See http://archives.chicagotribune.com/1960/03/20/page/53/article/little-rock-chief-killswife-and-self, last accessed on November 12, 2015.

9 Drawn from a presentation given on April 5, 2014, at the workshop on new forms of mediations, organised by Michael Houseman and Marika Moisseeff (Collège de France, Paris).

\section{REFERENCES}

Ansión, Juan 1989. Pishtacos: De verdugos a sacaojos. Lima: Tarea.

Aron, Matthieu \& Cognard, Franck 2014. Folles rumeurs: Les nouvelles frontières de l'intox. Paris: Stock.

Barthes, Roland 1972. Structure of the Fait Divers (orig. publ. 1962 in Médiations). In: R. Barthes. Critical Essays. Transl. by Richard Howard. Evanston: Northwestern University Press, pp. 185-196.

Belmont, Nicole 1984 [1968-1974]. Folklore. Encyclopedia Universalis. Paris: Ed. Encyclopedia Universalis. Available at http://www.universalis.fr/encyclopedie/folklore/, last accessed November 11, 2015.

Beneux, Laurence \& Garde, Serge 2001. Le livre de la honte: Les réseaux pédophiles. Paris: Le Cherche Midi.

Bensussan, Paul \& Rault, Florence 2002. La dictature de l'émotion: La protection de l'enfant et ses dérives. Paris: Belfond.

Best, Joel 1987. Rhetoric in Claims-Making: Constructing the Missing Children Problem. Social Problems, Vol. 34, No. 2, pp. 101-121. http://dx.doi.org/10.1525/ sp.1987.34.2.03a00010.

Best, Joel 1990. Threatened Children: Rhetoric and Concern About Child-Victims. Chicago \& London: The University of Chicago Press.

Best, Joel 2001. Damned Lies and Statistics: Untangling Numbers from the Media, Politicians, and Activists. Berkeley \& Los Angeles \& London: University of California Press.

Best, Joel 2002. Constructing the Sociology of Social Problems: Spector and Kitsuse Twenty-Five Years Later. Sociological Forum, Vol. 17, No. 4, pp. 699-706. Available at http://link.springer.com/article/10.1023/A\%3A1021037709754, last accessed on September 15, 2015.

Black, Tim 2013. Jimmy Savile: The Satanic Panic Resurrected. Jean La Fontaine on the Savile Case's Eerie Echoes of Past Hysteria. Spiked, July 1. Available at http://www.spiked-online.com/newsite/article/jimmy_savile_the_satanic_panic_ resurrected1/13765\#.VfFal31y73U, last accessed on September 10, 2015.

Brandon, S. \& Boakes, J. \& Glaser, D. \& Green, R. 1998. Recovered Memories of Childhood Sexual Abuse: Implications for Clinical Practice. The British Journal of Psychiatry, Vol. 172, pp. 296-307. http://dx.doi.org/10.1192/bjp.172.4.296. 
Brunvand, Jan Harold 1986. The Mexican Pet: More "New" Urban Legends and Some Old Favorites. New York \& London: W.W. Norton \& Company.

Burger, Peter 2014a. AD brengt gerucht als nieuws: Kris en Lisanne slachtoffer van orgaanroof. [AD Presents Rumour as News: Kris and Lisanne Victims of Organ Harvesting.] Available at http://www.gestolengrootmoeder.nl/wordpress/geruchtals-nieuws-vermiste-kris-en-lisanne-slachtoffer-van-orgaanroof/, last accessed on September 15, 2015.

Burger, Peter 2014b. Monsterlijke verhalen: Misdaadsagen in het nieuws en op webforums als retorische constructies. [Monster Tales: Crime Legends in the News and on Internet Forums as Rhetoric Constructions.] Den Haag: Boom Lemma.

Campion-Vincent, Véronique 1990. The Baby-Parts Story: A New Latin American Legend. Western Folklore, Vol. 49, No. 1 (Special issue: Contemporary Legends in Emergence), pp. 9-25. http://dx.doi.org/10.2307/1499480.

Campion-Vincent, Véronique 1997. Organ Theft Narratives. Western Folklore, Vol. 56, No. 1, pp. 1-37. http://dx.doi.org/10.2307/1500384.

Campion-Vincent, Véronique 2004. The Social Climate and Scare Stories about Children: An Overview and Evaluation. In: A. Palàdi-Kovàcs (ed.) Times, Places, Passages: Ethnological Approaches in the New Millennium. 7th SIEF Conference, Budapest, April 23-28, 2001. Selected Papers. Budapest: Akadémiai Kiadó, pp. 481-495.

Campion-Vincent, Véronique 2005. Organ Theft Legends. Transl. by Jacqueline Simpson. Jackson, MS: University Press of Mississippi.

Campion-Vincent, Véronique 2006. Élites maléfiques et 'complot pédophile': paniques morales autour des enfants. Schweizerisches Archiv für Volkskunde / Archives suisses des traditions populaires, Vol. 102, No. 1, pp. 49-70. Available at http:// retro.seals.ch/digbib/view?rid=sav-001:2006:102::62\&id=browse\&id2=browse2, last accessed on September 15, 2015.

Campion-Vincent, Véronique 2008. Comme un abus d'enfance. Paris: Seuil.

Conrad, Joann 1998. Stranger Danger: Defending Innocence, Denying Responsibility. Contemporary Legend, Vol. 1, pp. 55-96. Available at http://collections.mun. $\mathrm{ca} / \mathrm{cdm} /$ compoundobject/collection/clegend/id/2335/rec/7, last accessed on September 15, 2015.

Cree, Vivienne \& Clapton, Gary \& Smith, Mark 2014. Moral Panics, Jimmy Savile and Social Work: A 21st Century Morality Tale. Discover Society, No. 4, January 6. Available at http://www.discoversociety.org/2014/01/06/moral-panicsjimmy-savile-and-social-work-a-21st-century-morality-tale/, last accessed on September 15, 2015.

Crews, Frederick C. 2004. The Trauma Trap. The New York Review of Books, Vol. 51, No. 4. Available at http://www.nybooks.com/articles/archives/2004/mar/11/thetrauma-trap/, last accessed on September 9, 2015.

Davey, Monica \& Goodnough, Abby 2007a. Doubts Rise as States Hold Sex Offenders after Prison. New York Times, March 4. Available at http://www.nytimes.com/2007/03/04/ us/04civil.html?pagewanted=all\&_r=0, last accessed on September 15, 2015.

Davey, Monica \& Goodnough, Abby 2007b. A Record of Failure at Center for Sex Offenders.

New York Times, March 5. Available at http://www.nytimes.com/2007/03/05/ us/05civil.html?pagewanted=all, last accessed on September 15, 2015.

Davey, Monica \& Goodnough, Abby 2007c. For Sex Offenders, a Dispute over Therapy's Benefits. New York Times, March 6. Available at http://www.nytimes. 
com/2007/03/06/us/06civil.html?pagewanted=all, last accessed on September 15, 2015.

Delay, Chérif \& Garde, Serge 2011. Je suis debout: L'aîné des enfants d'Outreau sort du silence. Paris: Le Cherche Midi.

Donadini-Rousseau, Mireille 1998. Le discours social de la rumeur et le monde vécu. Montréal: Université du Québec à Montréal.

Egan, R. Danielle 2013. Moral Crusades in an Age of Mistrust: The Jimmy Savile Scandal by Frank Furedi. Times Higher Education Supplement, May 23. Available at https://www.timeshighereducation.co.uk/books/moral-crusades-in-an-age-ofmistrust-the-jimmy-savile-scandal-by-frank-furedi/2003935.article, last accessed on September 16, 2015.

Fass, Paula S. 1997. Kidnapped: Child Abduction in America. New York \& Oxford: Oxford University Press.

Furedi, Frank 2013a. Moral Crusades in an Age of Mistrust: The Jimmy Savile Scandal. Basingstoke, UK: Palgrave Macmillan. DOI: 10.1057/9781137338020.

Furedi, Frank 2013b. After Savile: Policing as Entertainment. Spiked, April 29. Available at http://www.spiked-online.com/newsite/article/13580\#.VFsmmDSG_nh, last accessed on September 10, 2015.

Garde, Serge 2013. Outreau l'autre vérité. Documentary.

Gray, David \& Watt, Peter 2013. Giving Victims a Voice. Available at http://content. met.police.uk/News/Giving-Victims-a-Voice/1400014181251/1257246745756, last accessed on September 10, 2015.

Gryson-Dejehansart, Marie-Christine 2009. Outreau la vérité abusée. Paris: Hugo et Compagnie.

Hume, Mike 2013. Operation Yewtree: Putting the Past on Trial. Spiked, January 14. Available at http://www.spiked-online.com/newsite/article/13251\#.VkXx517pYQ1, last accessed on November 11, 2015.

Jenkins, Philip 1996. Paedophiles and Priests: Anatomy of a Contemporary Crisis. Oxford \& New York: Oxford University Press.

Jenkins, Philip 1998. Moral Panic: Changing Concepts of the Child Molester in Modern America. New Haven \& London: Yale University Press.

Journal Officiel $1995=$ Loi n $^{\circ}$ 95-73 du 21 janvier 1995 d'orientation et de programmation relative à la sécurité. Article 26. Légifrance. Available at http://www.legifrance. gouv.fr/affichTexte.do?cidTexte=LEGITEXT000005617582, last accessed on September 16, 2015.

Kempe, C. Henry \& Silverman, Frederic M. \& Steele, Brandt F. \& Droegemueller, William \& Silver, Henry K. 1962. The Battered Child Syndrome. Journal of the American Medical Association, Vol. 181, No. 1, pp. 17-24.

Klintberg, Bengt af 2014. The Human Sausage Factory: A Study of Post-War Rumour in Tartu. Journal of Baltic Studies, Vol. 45, No. 2, pp. 272-274. DOI:10.1080/0 1629778.2014.892245.

La Fontaine, Jean S. 1998. Speak of the Devil: Tales of Satanic Abuse in Contemporary England. Cambridge: Cambridge University Press.

Larousse, Pierre (ed.) 1869. Grand Dictionnaire universel du XIX ${ }^{e}$ siècle. Vol. 4. Paris: Administration du Grand Dictionnaire Universel. Available at http://www. archive.org/stream/LarousGrdictionnXIX04bnf\#page/n10/mode/1up, last accessed on September 16, 2015. 
Lévi-Strauss, Claude 1962. La pensée sauvage. Paris: Plon. Available at http://monoskop. org/images/f/f6/Levi-Strauss_Claude_La_Pensee_sauvage_1962.pdf, last accessed on November 16, 2015.

Lienhardt, Peter 1975. The Interpretation of Rumour. In: J. H. M. Beattie \& R. G. Lienhardt (eds.) Studies in Social Anthropology: Essays in Memory of E. E. EvansPritchard. Oxford: Clarendon Press, pp. 105-131.

Loftus, Elizabeth \& Ketcham, Katherine 1994. The Myth of Repressed Memory: False Memories and Allegations of Sexual Abuse. New York: St Martin's Press.

Luccioni, Isabelle 2013. A Ajaccio, la rumeur de sévices sexuels a failli tourner au lynchage. Corse-Matin, September 2. Available at http://www.corsematin. com/article/ajaccio/a-ajaccio-la-rumeur-de-sevices-sexuels-a-failli-tourner-aulynchage.1130991.html, last accessed on September 14, 2015.

Molinié Fioravanti, Antoinette (ed.) 1991. El Pishtaco. Bulletin de l'Institut Français d'Etudes Andines, Vol. 20, No. 1, pp. 1-92. Available at http://www.ifeanet.org/ publicaciones/detvol.php?codigo=178, last accessed on November 16, 2015.

Moore, Suzanne 2013. Moral Crusades in an Age of Mistrust: The Jimmy Savile Scandal Crusades by Frank Furedi. Review. The Guardian, March 13. Available at http:// www.theguardian.com/books/2013/mar/13/moral-crusades-frank-furedi-review, last accessed on September 10, 2015.

Rey, Alain (ed.) 1994. Dictionnaire historique de la langue française. Vol. 1. Paris: Dictionnaires Le Robert.

Richardson, James T. \& Best, Joel \& Bromley, David G. (eds.) 1991. The Satanism Scare: An Anthropological View. New York: Aldine de Gruyter.

Roper, Derek 1997. More Mall Kidnapping Stories. FoafTale News, Vol. 42, No. 10. Available at http://www.folklore.ee/FOAFtale/ftn42.htm, last accessed on September 8, 2015.

Rouquette, Michel-Louis 1973. La pensée sociale. In: S. Moscovici (ed.) Introduction à la psychologie sociale, Vol. 2. Paris: Larousse, pp. 298-328. Available at http:// classiques.uqac.ca/contemporains/moscovici_serge/intro_psycho_soc_t2/intro_ psycho_soc_t2.pdf, last accessed on September 16, 2015.

Spector, Malcolm \& Kitsuse, John I. 1987. Constructing Social Problems. New York: Aldine de Gruyter.

Tardieu, Ambroise 1857. Étude médico-légale sur les attentats aux mœurs. Paris: J. B. Baillière et Fils.

Tardieu, Ambroise 1860. Étude médico-légale sur les sévices et les mauvais traitements exercés sur des enfants. Annales d'hygiène publique et de médecine légale, $2 \mathrm{e}$ série, tome XIII, pp. 361-398.

Thomet, Jacques 2013. Retour à Outreau: Contre-enquête sur une manipulation pédocriminelle. Paris: Kontre Kulture.

Turner, Patricia A. 1993. I Heard It Through the Grapevine: Rumour in African-American Culture. Berkeley \& Los Angeles \& London: University of California Press.

Van der Kolk, B. A. \& Van der Hart, Onno 1991. The Intrusive Past: The Flexibility of Memory and the Engraving of Trauma. American Imago, Vol. 48, No. 4, pp. 425454. Available at http://www.pep-web.org/toc.php?journal=aim\&volume=48, last accessed on September 9, 2015.

Zéro, Karl 2014. Disparues: Que sont-elles devenues? Paris: L’Archipel. 